\title{
Low doses of Co nanoparticles induce death and regulate osteogenic differentiation in MG-63 cells
}

\author{
QINGLIN HAN and FAN LIU
}

\begin{abstract}
Orthopaedic Department, The Affiliated Hospital of Nantong University, Nantong, Jiangsu 226001, P.R. China
\end{abstract}
Received June 13, 2016; Accepted April 10, 2017

DOI: $10.3892 / \mathrm{mmr} .2017 .7512$

\begin{abstract}
The aim of the present study was to investigate the effects of cobalt nanoparticles (CoNPs) on the proliferation and differentiation of human osteoblasts in vitro, and to investigate the molecular mechanisms via which CoNPs affect proliferation and differentiation of osteoblasts. The MG-63 human osteoblast cell line was treated with different concentrations of CoNPs for 12 to $48 \mathrm{~h}$ in vitro. At each time point, cell morphology was observed and an MTT assay was performed to assess cell viability. Alkaline phosphatase (ALP), osteocalcin (BGLAP), collagen I (COL I), osteoprotegerin (OPG) and receptor activator of nuclear factor $\kappa-B$ ligand mRNA expression levels, and ALP, BGLAP and COL protein expression levels, were assessed by reverse transcription-quantitative polymerase chain reaction and western blotting, respectively. The viability of MG-63 cells decreased significantly after treatment with CoNPs. As CoNP concentration increased, a higher growth inhibition and cell death was observed. Compared with CoNPs, treatment with the same concentration of $\mathrm{Co}^{2+}$ may have a greater inhibitory effect on the growth of MG-63 cells. CoNPs affected the mRNAs expression levels of ALP, BGLAP, COL I and OPG in MG-63 cells, and reduced the protein expression levels of ALP, BGLAP and COL I. In conclusion, the present study demonstrated that CoNPs induce cytotoxic effects on MG-63 cells by markedly reducing cell viability and inducing cell death at high concentrations. In addition, CoNPs may inhibit the function and differentiation of osteoblasts by affecting the mRNA and protein expression levels of associated genes. The results of the present study indicate that CoNPs may serve an important role in the aseptic loosening mechanism following total joint replacement surgery, particularly in situations where metal on metal prostheses are used. Further study into inhibiting this effect is required.
\end{abstract}

Correspondence to: Dr Fan Liu, Orthopaedic Department, The Affiliated Hospital of Nantong University, 20 Xisi Road, Nantong, Jiangsu 226001, P.R. China

E-mail: 1975hanql@163.com

Key words: cobalt nanoparticles, MG-63, osteoblast

\section{Introduction}

In recent years, there has been a marked increase in the number of joint replacement surgeries. According to Food and Drug Administration records, 400,000 hip arthroplasty procedures are performed every year in the US alone (1). As metals and metal prosthesis exhibit remarkable stability and abrasion resistance, they have been widely used in surgeries involving joint replacement and bone damage repair (2). However, abrasion and invasion of the prosthesis have been demonstrated to release large amounts of metal particles and ions, with the major components being cobalt (Co) and chromium (Cr) particles (3). Several recent studies have discussed the toxic effects of increased whole blood levels of $\mathrm{Co}$ and $\mathrm{Cr}$ following metal-on-metal hip arthroplasties and other orthopedic surgical procedures that involve prosthetic implants (4-7). However, the potential risks of increased $\mathrm{Co}-\mathrm{Cr}$ levels and their safety levels remain to be established (8).

It is understood that no biomaterials are completely inert, and an interaction between the material and human body often elicits an immune response. Metallic implants have been reported to break down or corrode over time, leading to release of soluble ions that may have both local and systemic effects (9). It is therefore important to identify the safe levels of these byproducts, and the risks associated with their elevated levels.

Several studies have monitored Co ion concentrations in patients following hip arthroplasties $(4,5)$. Certain patients were suspected to exhibit symptoms of cobalt toxicity (mostly neurological dysfunction), as identified by previous cases of inhalation and ingestion of excess cobalt (8). However, the mechanism of cobalt toxicity remains to be identified, and there is no comparative data on symptomatic and asymptomatic patients with cobalt-containing metal alloy prosthetics.

In vitro studies have demonstrated that at concentrations higher than $100 \mu / 1$, Co nanoparticles (CoNPs) and Co ions reduce the viability of MG-63 cells, inhibit cell growth and induce apoptosis (10-14). Both $\mathrm{Co}(2+)$ and $\mathrm{Cr}(6+)$ cause a reduction in numbers of and resorption in mature osteoclasts $(15,16)$. A study on SaOS-2 osteoblast-like cells has demonstrated that exposure to $\mathrm{Co}$ and $\mathrm{Cr}$ ions and nanoparticles affect osteoblast function and mineralization of the prosthesis surface (17). CoNPs and ions have also exhibited biological toxicity against monocytes (18), and affect osteogenic differentiation 
of mesenchymal stem cells (19). Intraperitoneal administration of cobalt has been revealed to alter serum parameters associated with bone metabolism, and may potentially induce bone resorption in adult rats (20). Mice osteoblasts treated with Co for $48 \mathrm{~h}$ in vitro exhibited changes in morphology and an increased secretion of the cytokine receptor activator of nuclear factor $\kappa$-B ligand (RANKL), which may activate osteolysis (21).

Several key transcription factors regulating different stages of skeletogenesis, and their modes of action and regulation by other factors have been studied in the past (22). It may be worthwhile to examine the effects of CoNPs on some of these key transcription factors.

To the best of our knowledge, there are no previous studies investigating whether low doses of CoNPs affect growth and differentiation of human osteoblasts. In the present study, MG-63 cells were treated with CoNPs and cell growth, survival and death were examined. Additionally, the expression levels of genes responsible for osteogenic differentiation, alkaline phosphatase (ALP), osteocalcin (BGLAP), collagen I (COL I) and osteoprotegerin (OPG) were detected.

\section{Materials and methods}

Cell line and reagents. The MG-63 human osteosarcoma cell line was purchased from the Shanghai Institute for Life Science, Chinese Academy of Sciences (Shanghai, China). The cells were cultured in Dulbecco's modified Eagle's medium (Gibco; Thermo Fisher Scientific, Inc., Waltham, MA, USA) supplemented with $10 \%$ fetal bovine serum (Gibco; Thermo Fisher Scientific, Inc.), $100 \mathrm{U} / \mathrm{ml}$ penicillin (Sigma-Aldrich; Merck KGaA, Darmstadt, Germany) and $100 \mu \mathrm{g} / \mathrm{ml}$ streptomycin sulfate (Sigma-Aldrich; Merck KGaA). The culture medium was changed every alternate day. Sterilized CoNPs (Shanghai ChaoWei Nanotechnology Co., Ltd, Shanghai, China) were prepared in PBS to obtain a concentration of $5 \mathrm{mM}$ and stored at room temperature. The solution was further diluted with PBS after ultrasonic oscillation to obtain different concentrations required for the experiment. Ultra-pure water was used to prepare $5 \mathrm{mM} \mathrm{CoCl}_{2}$ solution, which was sterilized by filtration, and stored at $4^{\circ} \mathrm{C}$ until use.

CoNP treatment. To assess alterations in cell morphology, MG-63 cells were seeded into 24 -well culture plates at a density of $4 \times 10^{5}$ cells/well, and treated with $0.01,0.1,0.3$ or $0.5 \mathrm{mg} / \mathrm{ml}$ of CoNPs for 12 or $24 \mathrm{~h}$. The control cells were treated with PBS. Cells were analyzed under an inverted microscope (Olympus Corporation, Tokyo, Japan).

MTT assay. MG-63 cells were seeded into 96-well culture plates at a density of $1 \times 10^{5}$ cells/well, and treated $0.01,0.1$, 1,10 or $100 \mathrm{mg} / \mathrm{ml}$ CoNPs or $\mathrm{Co}^{2+}$ for $6,12,24$ and $48 \mathrm{~h}$ in triplicate. Control cells were treated with PBS. A total of $20 \mu 15 \mathrm{mg} / \mathrm{ml} \mathrm{3-(4,5)-dimethylthiahiazo} \mathrm{(-z-y1)-3,5-di-}$ phenytetrazoliumromide (Sigma-Aldrich; Merck KGaA) was added into each well after the treatment and cultured for $2 \mathrm{~h}$. The cells were then centrifuged at $94 \mathrm{x} \mathrm{g}$ for $20 \mathrm{~min}$ at room temperature, the supernatant was discarded and $50 \mu$ l dimethyl sulfoxide was added into each well. The cells were oscillated at low frequency for $10 \mathrm{~min}$ until the crystals
Table I. Primer sequences for reverse transcription-quantitative polymerase chain reaction.

\begin{tabular}{ll} 
Gene & \multicolumn{1}{c}{ Primer sequence } \\
\hline ALP & F: 5'-GCCCTAAGGTCCATTCCA-3' \\
& R: 5'-CTTTGTGTTTCCCAGAAGAATG-3' \\
BGLAP & F: 5'-CAACCCCAGTTCTGCTCCT-3' \\
& R: 5'-CCTCTTCTGGAGTTTATTTGGG-3' \\
COL I & F: 5'-TCAATCCCTTGTGCCGC-3' \\
& R: 5'-CACATCAAGACAAGAACGAGGTA-3' \\
OPG & F: 5'-GCAGCGGCACATTGGAC-3' \\
& R: 5'-CCCGGTAAGCTTTCCATCAA-3' \\
RANKL & F: 5'-AGAGCGCAGATGGATCCTAA-3' \\
& R: 5'-TTCCTTTTGCACAGCTCCTT-3' \\
$\beta$-actin & F: 5'-ATGACTTAGTTGCGTTACACCCTT-3' \\
& R: 5'-GCTGTCACCTTCACCGTTCC-3'
\end{tabular}

F, forward; R, reverse; ALP, alkaline phosphatase; BGLAP, osteocalcin; COL I, collagen I; OPG, osteoprotegerin; RANKL, receptor activator of nuclear factor $\kappa-\mathrm{B}$ ligand.

Table II. X Ray fluorescence analysis of cobalt nanoparticles.

\begin{tabular}{lcc}
\hline Element & Content/wt.\% & Standard deviation \\
\hline $\mathrm{Co}$ & 99.9 & 0.001 \\
$\mathrm{Fe}$ & 0.002 & 0.003 \\
$\mathrm{Ag}$ & 0.001 & 0.001 \\
$\mathrm{Cu}$ & 0.002 & 0.003 \\
$\mathrm{~W}$ & 0.004 & 0.006 \\
$\mathrm{Ni}$ & 0.009 & 0.002 \\
$\mathrm{~N}$ & 0.01 & 0.007 \\
$\mathrm{O}$ & $<0.07$ & \\
\hline
\end{tabular}

dissolved completely. The optical density at a wavelength of $570 \mathrm{~nm}$ was read by a microplate reader (calibrated at $630 \mathrm{~nm})$.

Reverse transcription-quantitative polymerase chain reaction $(R T-q P C R)$. Cellular RNA was extracted using RISO RNA isolation reagent (Biomics USA, Co., Ltd., San Francisco, CA, USA) according to the manufacturer's protocol. cDNA preparation was carried out by reverse transcription as follows: $2 \mu \mathrm{g}$ total RNA, $1 \mu \mathrm{l}$ oligo (dT) 18 primer, $4 \mu \mathrm{l}$ 5X Reaction Buffer, $1 \mu$ l Ribolock ${ }^{\mathrm{TM}}$ RNase inhibitor (Fermentas; Thermo Fisher Scientific, Inc.), $2 \mu 110$ mM dNTP Mix, $1 \mu 1$ RevertAid $^{\mathrm{TM}}$ M-MLV Reverse Transcriptase (Takara Biotechnology Co. Ltd., Dalian, China), and $9 \mu 1$ diethyl pyrocarbonate. The mixture was incubated at $42^{\circ} \mathrm{C}$ for $60 \mathrm{~min}$, followed by incubation at $70^{\circ} \mathrm{C}$ for $5 \mathrm{~min}$ to end the reaction. The products were stored at $-20^{\circ} \mathrm{C}$ until use.

For qPCR, a SYBR Green kit (Roche Diagnostics GmbH, Mannheim, Germany) was used with an Applied Biosystems 7500 Real Time PCR instrument. The $20 \mu 1$ reaction mix 

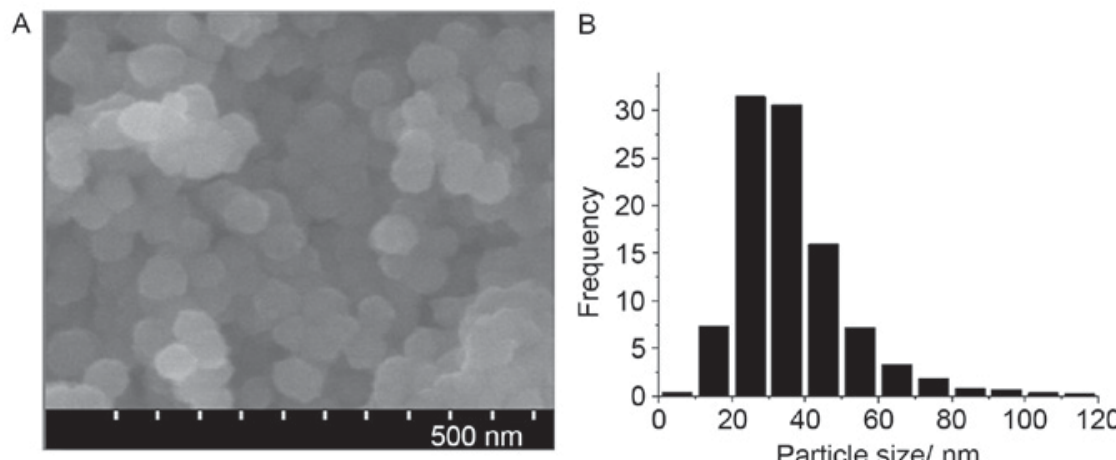

Figure 1. (A) Size and (B) distribution of the cobalt nanoparticles used in the present study by electron microscopy and X-ray diffraction assessment.

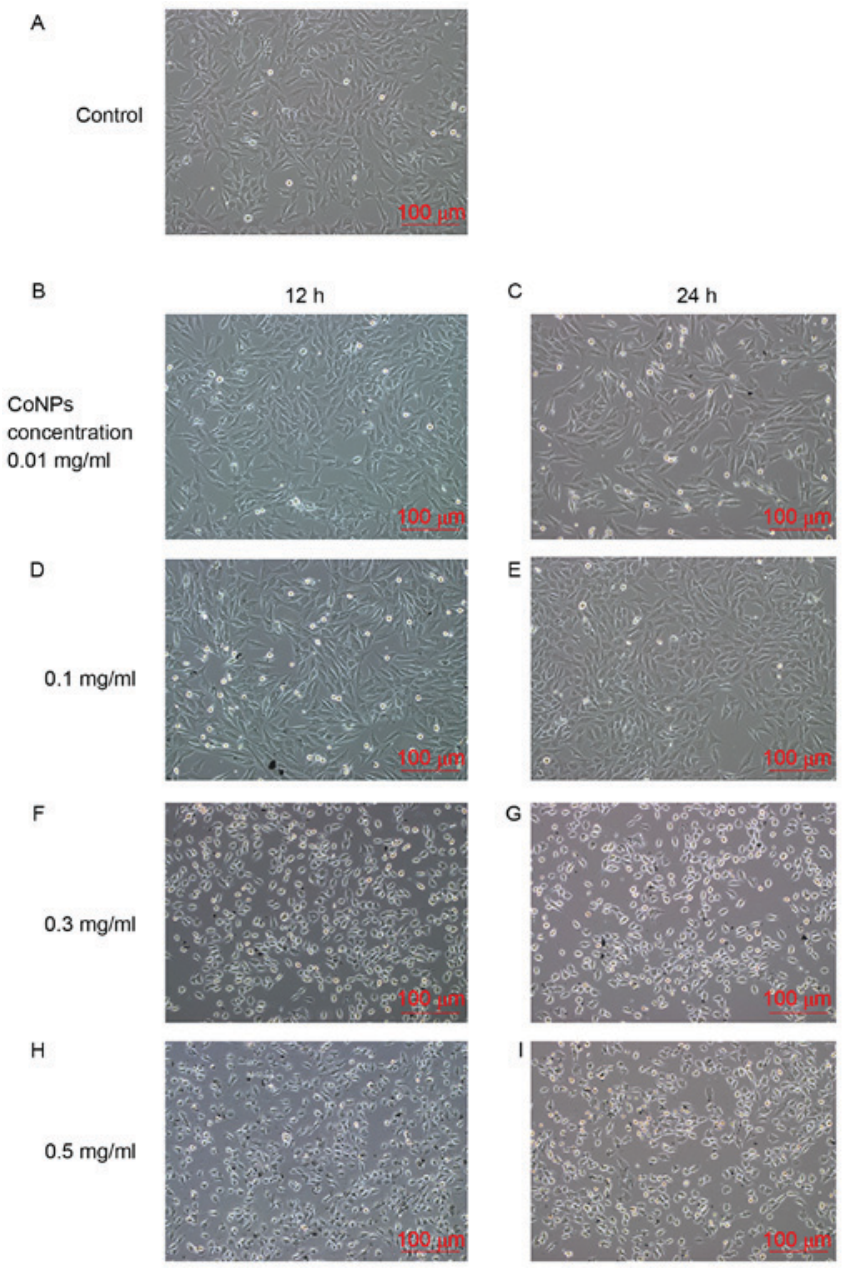

Figure 2. Effect of varying concentrations of CoNPs on the morphology of MG-63 cells after 12 and 24 h. (A) Untreated control MG-63 cells. MG-63 cells treated with $0.01 \mathrm{mg} / \mathrm{ml} \mathrm{CoNPs}$ for (B) 12 and (C) $24 \mathrm{~h}$. MG-63 cells treated with $0.1 \mathrm{mg} / \mathrm{ml}$ CoNPs for (D) 12 and (E) $24 \mathrm{~h}$. MG-63 cells treated with $0.3 \mathrm{mg} / \mathrm{ml} \mathrm{CoNPs}$ for (F) 12 and (G) $24 \mathrm{~h}$. MG-63 cells treated with $0.5 \mathrm{mg} / \mathrm{ml}$ CoNPs for (H) 12 and (I) $24 \mathrm{~h}$. CoNPs, cobalt nanoparticles.

was prepared as follows: $10 \mu \mathrm{l} 2 \mathrm{X}$ Master Mix buffer, $1.2 \mu \mathrm{l}$ forward and reverse primers each $(10 \mathrm{mM}), 1 \mu \mathrm{lDNA}$ and $6.6 \mu 1$ double distilled water. The primer sequences for ALP, BGLAP, COL I, OPG, RANKL and GAPDH are listed in Table I. The PCR conditions were as follows: Initial denaturation at $95^{\circ} \mathrm{C}$ for $10 \mathrm{~min}$, followed by denaturation at $95^{\circ} \mathrm{C}$ for $10 \mathrm{sec}$, and annealing and extension at $60^{\circ} \mathrm{C}$ for $30 \mathrm{sec}$ for 40

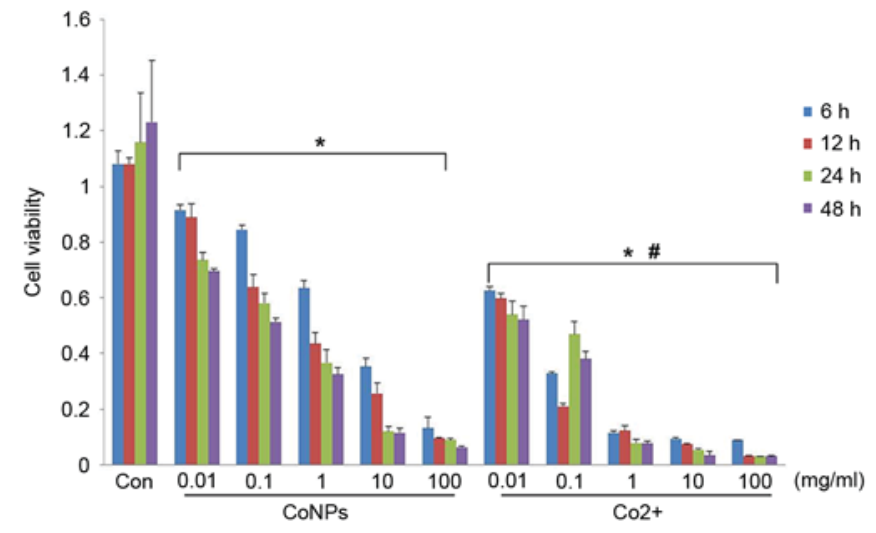

Figure 3. Effect of varying concentrations of CoNPs and $\mathrm{Co}^{2+}$ on the viability of MG-63 cells, as observed by MTT assay. Data are expressed as the mean \pm standard deviation. ${ }^{~} \mathrm{P}<0.05$ vs. control group at the same time point; ${ }^{\text {"}} \mathrm{P}<0.05$ vs. CoNPs groups at the same time point. CoNPs, cobalt nanoparticles; $\mathrm{Co}^{2+}$, cobalt ions.

cycles. The RNA levels were calculated by the $2^{-\Delta \Delta C q}$ method using $\beta$-actin as an internal reference (23).

Western blotting. The cells were lysed on ice with $1 \mathrm{X}$ radioimmnoprecipitation assay buffer $[20 \mathrm{mM}$ Tris- $\mathrm{HCl}$ (pH 7.5); 150 mM NaCl; 1 mM Na${ }_{2}$ EDTA; 1 mM EGTA; $1 \%$ $\mathrm{NP}-40,1 \%$ sodium deoxycholate; $2.5 \mathrm{mM}$ sodium pyrophosphate; $1 \mathrm{mM} \beta$-glycerophosphate; $1 \mathrm{mM} \mathrm{Na}_{3} \mathrm{VO}_{4 ;} 1 \mu \mathrm{g} / \mathrm{ml}$ leupeptin] for $30 \mathrm{~min}$, and then centrifuged at $15,871 \mathrm{x} \mathrm{g}$ for $30 \mathrm{~min}$ at room temperature. The supernatant was collected and stored at $-80^{\circ} \mathrm{C}$ until use. The protein concentration was determined by the Pierce BCA Protein Assay kit (Thermo Fisher Scientific, Inc.). Total protein $(30 \mu \mathrm{g})$ was separated by $10 \%$ SDS-PAGE and transferred onto polyvinylidene difluoride membranes. Following blocking in PBS $+5 \%$ non-fat milk for $1 \mathrm{~h}$ at room temperature, the membranes were incubated with ALP, COL I, BGLAP and $\beta$-actin primary antibodies at $4^{\circ} \mathrm{C}$ overnight, as follows: ALP, 1:1,000, cat. no. SAB2500128; COL I, 1:1,000, cat. no. SAB4200678; BGLAP, 1:1,000, cat. no. WH0000632M1; $\beta$-actin, 1:5,000, cat. no. A1978; all purchased from Sigma-Aldrich; Merck KGaA. The membranes were washed with TBS $+0.1 \%$ Tween-20 and incubated with the following peroxidase-conjugated secondary antibodies for $2 \mathrm{~h}$ at room temperature: Goat anti-mouse immunoglobulin (Ig)G 

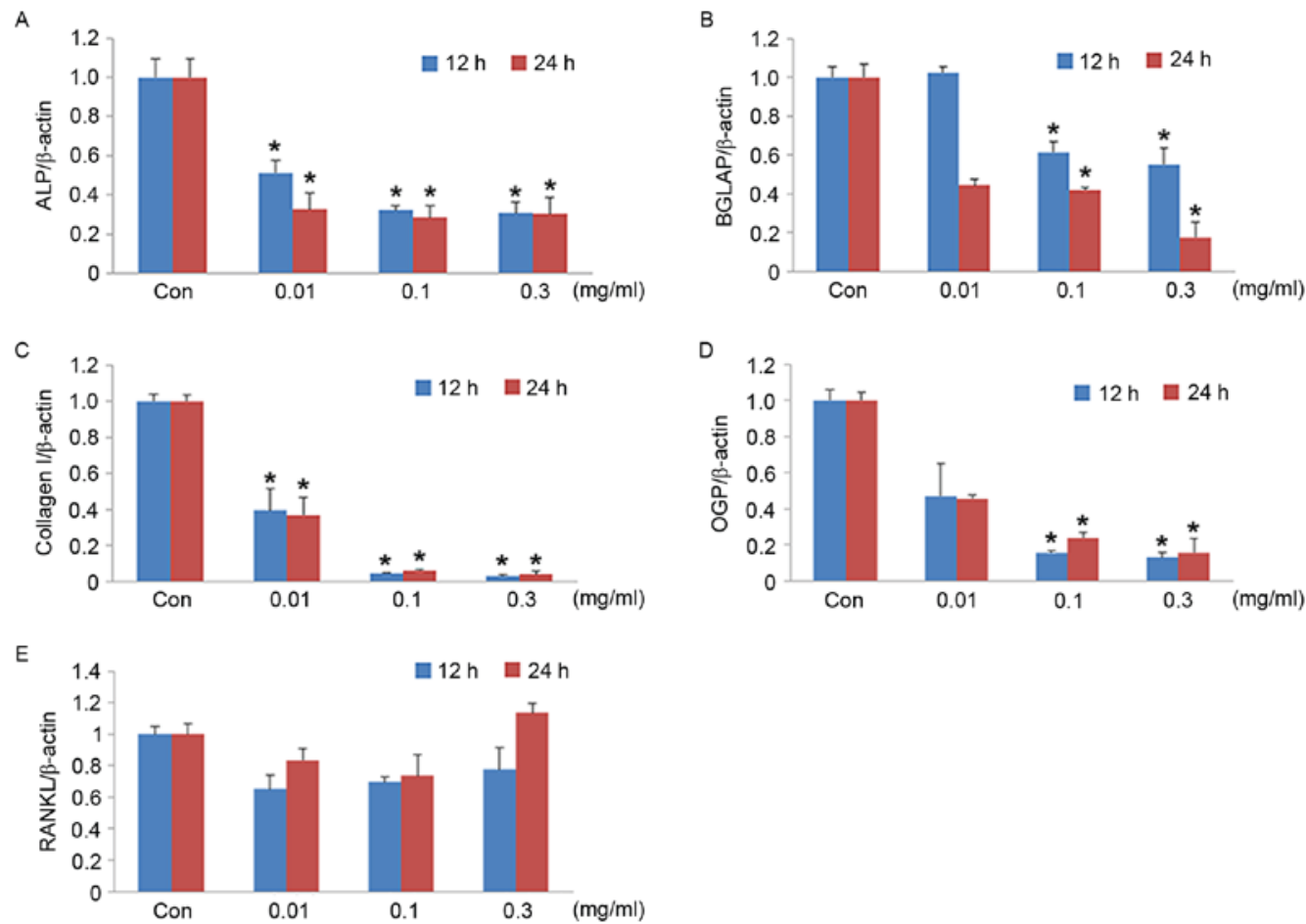

Figure 4. mRNA expression levels in MG-63 cells. Quantification of (A) ALP, (B) BGLAP, (C) COL I, (D) OPG AND (E) RANKL mRNA expression levels following treatment with $0.01,0.1$ and $0.3 \mathrm{mg} / \mathrm{ml}$ of cobalt nanoparticles for 12 and $24 \mathrm{~h}$. $\beta$-actin served as an internal control. Data are expressed as the mean \pm standard deviation. ${ }^{~} \mathrm{P}<0.05$ vs. control group at the same time point. ALP, alkaline phosphatase; BGLAP, osteocalcin; COL I, collagen I; OPG, osteoprotegerin; RANKL, receptor activator of nuclear factor $\mathrm{\kappa}-\mathrm{B}$ ligand; Con, control.

(1:5,000; cat. no. A3682) and rabbit anti-goat IgG (1:5,000; cat. no. A8919) (both from Sigma-Aldrich; Merck KGaA). An Enhanced Chemiluminescence assay (EMD Millipore, Billerica, MA, USA) was used to detect proteins, and images were captured using a gel imaging system (VersaDoc Imaging System, Bio-Rad Laboratories, Inc., Hercules, CA, USA) and the densitometry was quantified using ImageJ 1.41 software (National Institutes of Health, Bethesda, MD, USA).

Statistical analysis. The above experiments were all repeated in triplicate. SPSS 19.0 software (IBM Corp., Armonk, NY, USA) was used for the statistical analysis. All the data are presented as the mean \pm standard deviation. For comparison of more than two groups, one-way analysis of variance followed by a Bonferroni-Dunn post hoc test was used. $\mathrm{P}<0.05$ was considered to indicate a statistically significant difference.

\section{Results}

Identification of CoNPs. CoNPs were observed via electron microscopy. The CoNPs were of homogenous size with the mean diameter being $50 \mathrm{~nm}$. X-ray diffraction demonstrated that the sizes of the particles were mainly between 20 and $40 \mathrm{~nm}$, and the percentage of Co was $99.9 \pm 0.001 \%$, while the other components including iron, silver, copper, tungsten and nickel were all $<0.01 \%$ (Table II; Fig. 1).

Effects of CoNPs on the morphology and viability of MG-63 cells. The MG-63 cells were treated with $0.01,0.1,0.3$ or $0.5 \mathrm{mg} / \mathrm{ml}$ of CoNPs for 12 or $24 \mathrm{~h}$ and then analyzed microscopically. The results indicated that the cell morphologies changed slightly after treatment with 0.01 and $0.1 \mathrm{mg} / \mathrm{ml}$ CoNPs. When the cells were treated with CoNPs at concentrations of $0.3 \mathrm{mg} / \mathrm{ml}$ or higher, retraction of cellular pseudopods, pyknosis of the cytoplasm and cell death was observed. Cell death was observed when incubated with CoNPs for $12 \mathrm{~h}$, and it increased further after $24 \mathrm{~h}$ and was accompanied by an increase in CoNP concentration. The highest cell death was observed in cells treated with $0.5 \mathrm{mg} / \mathrm{ml}$ of CoNPs for $24 \mathrm{~h}$ (Fig. 2).

MTT assay was used to evaluate cell viability after treatment with different concentrations of CoNPs or $\mathrm{Co}^{2+}$ for 6,12 , 24 or $48 \mathrm{~h}$. After treatment with different concentrations of CoNPs or $\mathrm{Co}^{2+}$ for $6 \mathrm{~h}$, the viability of the cells was significantly reduced compared with the control group $(\mathrm{P}<0.05)$. Cell viability decreased in a dose-dependent manner. In comparison to CoNPs, a reduction in cell viability was more pronounced at the same concentration of $\mathrm{Co}^{2+}(\mathrm{P}<0.05)$. The reduction in cell viability increased with an increase in the duration of treatment, and peaked at $48 \mathrm{~h}$ (Fig. 3).

Effects of CoNPs on mRNA and protein expression levels of ALP, $B G L A P$, Col I, OGP and RANKL. RT-qPCR was performed to evaluate the mRNA expression of ALP, BGLAP, Col I, OGP and RANKL in MG-63 cells treated with different concentrations of CoNPs. After the cells were treated with 0.01, 0.1 and $0.3 \mathrm{mg} / \mathrm{ml}$ CoNPs for 12 or $24 \mathrm{~h}$, the mRNA expression levels of ALP, BGLAP, COL I and OPG decreased significantly $(\mathrm{P}<0.05)$ in a concentration-dependent manner. An upward trend in RANKL mRNA levels were observed at a CoNP concentration of $0.3 \mathrm{mg} / \mathrm{ml}$; however, this increase was not statistically significant (Fig. 4). The reduction in mRNA expression levels was 
A

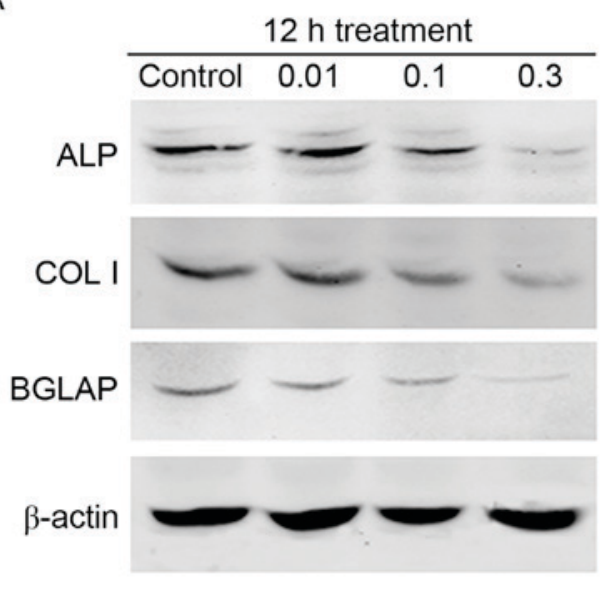

C

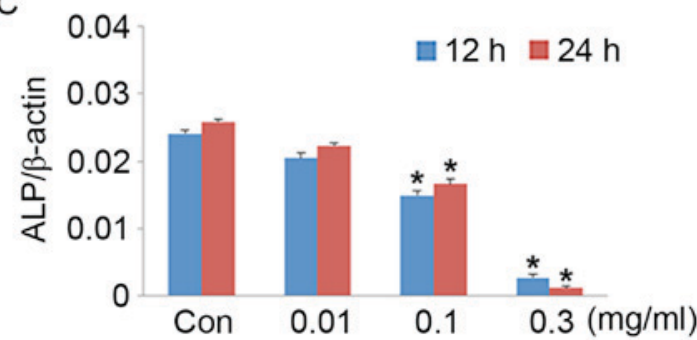

B
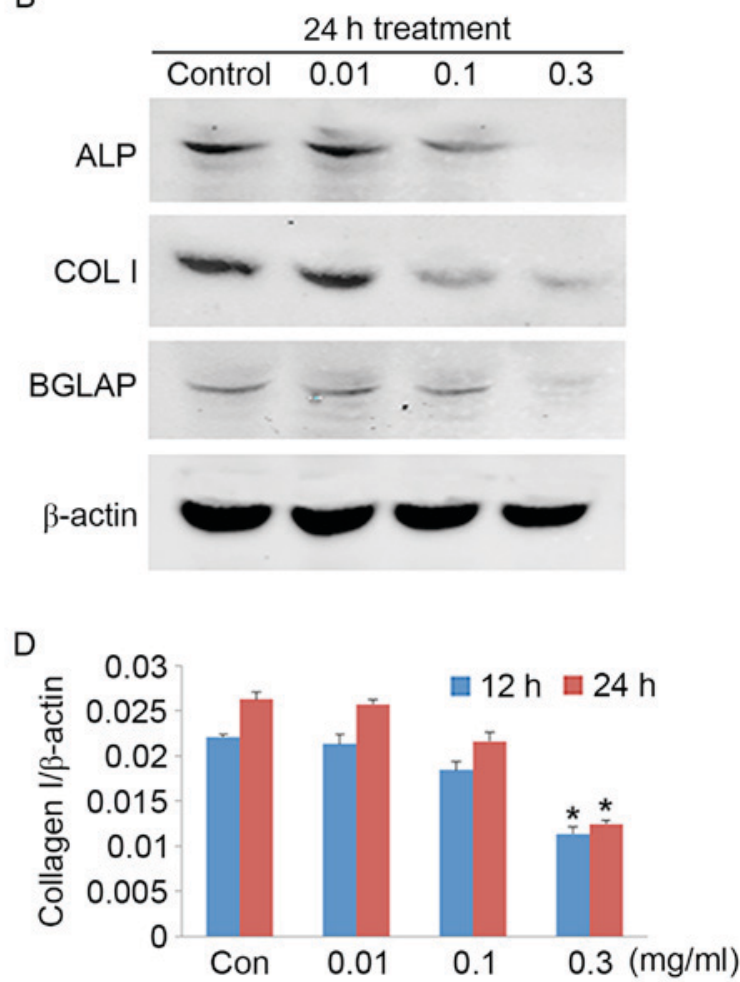

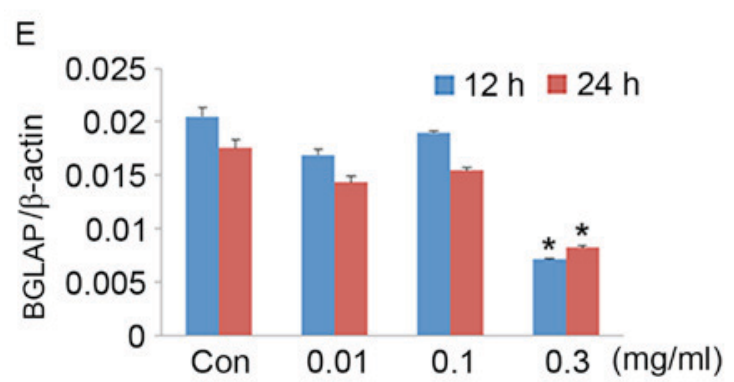

Figure 5. Protein expression levels in MG-63 cells. Representative western blot images after (A) 12 and (B) 24 h of protein expression levels of (C) ALP, (D) COL I and (E) BGLAP. MG-63 cells were treated with $0.01,0.1$ or $0.3 \mathrm{mg} / \mathrm{ml}$ cobalt nanoparticles. $\beta$-actin served as an internal control. Data are expressed as the mean \pm standard deviation. "P<0.05 vs. control group at the same time point. ALP, alkaline phosphatase; BGLAP, osteocalcin; COL I, collagen I; Con, control.

also confirmed by measuring the protein expression levels by western blotting (Fig. 5). The ALP, BGLAP and COL I protein expression levels decreased significantly when the cells were treated with $0.3 \mathrm{mg} / \mathrm{ml}$ CoNPs for $12 \mathrm{~h}$. Thus, CoNPs affected the mRNA and protein expression levels of ALP, BGLAP and COL I in MG-63 cells in a concentration-dependent manner, and may affect osteogenesis.

\section{Discussion}

The findings of the present study show demonstrated increased cell death and decreased survival in CoNP-treated MG-63 cells. In addition, CoNP treatment affected the mRNA and expression levels of ALP, BGLAP, COL I and OPG, genes responsible for osteogenic differentiation, and the protein expression levels of ALP, COL I and BGLAP.

Previous studies on mice osteoblasts and animal models have revealed that $\mathrm{Co}^{2+}$ and $\mathrm{Cr}^{3+}$ may inhibit the proliferation of mice osteoblasts, and induce cytotoxic effects on cells. In human osteoblasts, CoNPs and $\mathrm{Co}^{2+}$ may also inhibit the proliferation of osteoblasts, cause cell apoptosis and induce the release of inflammatory cytokines such as tumor necrosis factor- $\alpha$ and interleukin-6 $(13,24,25)$. The present study also confirmed that CoNPs at concentrations between 0.01 and $0.5 \mathrm{mg} / \mathrm{ml}$ may inhibit the growth of osteoblasts.

High concentrations of CoNPs have been demonstrated to induce cell apoptosis (16). Further investigation on the functions of osteoblasts and expression of relevant genes revealed that CoNPs could inhibit the functions of osteoblasts, reduce the expression levels of ALP and COL I, genes that are required for bone matrix maturation, and decrease the expression of the BGLAP gene that is required for mineralization (26). The process of osteolysis has also been identified to be regulated by CoNPs, which may downregulate the inhibitory RANKL ligand OPG to increase bone absorption of osteoclasts (27). The results of the present study also indicated that in MG-63 cells, both mRNA and protein expression levels of genes responsible for osteogenic differentiation, ALP, BGLAP, COL I and OGP, are affected by low levels of CoNP treatment. Therefore, CoNPs may not only affect the growth and 
differentiation of osteoblasts, but also indirectly upregulate the lysis and absorption of the bone by osteoclasts.

Metal prostheses can release large amounts of $\mathrm{Co}^{2+}$ and CoNPs due to biological and chemical corrosion, mechanical abrasion and oxidation of the metals (16). Andrews et al (16) demonstrated that $\mathrm{Co}^{2+}$ potentially had a greater inhibitory effect on the growth of MG-63 cells compared with CoNPs, and the IC50 for inhibiting the growth of MG-63 cells was lower than CoNPs. $\mathrm{Co}^{2+}$ can diffuse in solutions more easily compared to CoNPs, which may be why there are more pronounced effects post-treatment with $\mathrm{Co}^{2+}$.

In conclusion, the present study demonstrated that CoNPs induce cytotoxic effects on MG-63 cells by markedly reducing cell viability and inducing cell death at high concentrations. In addition, CoNPs may inhibit the function and differentiation of osteoblasts by affecting the mRNA and protein expression levels of associated genes. These results revealed the potential negative effect of CoNPs on prosthesis aseptic loosening following total joint replacement surgery. Inhibition of this effect should be further investigated.

\section{References}

1. Administration TUSFaD: Information for all health care professionals who provide treatment to patients with a metal-on-metal hip implant, 2015. https://www.fda.gov/MedicalDevices/ ProductsandMedicalProcedures/ImplantsandProsthetics/ MetalonMetalHipImplants/ucm241744.htm. Accessed January 9, 2015.

2. Fathi M, Ahmadian M and Bahrami M: Novel bioactive Co-based alloy/FA nanocomposite for dental applications. Dent Res J (Isfahan) 9: 173-179, 2012.

3. MacQuarrie RA, Fang Chen Y, Coles C and Anderson GI: Wear-particle-induced osteoclast osteolysis: The role of particulates and mechanical strain. J Biomed Mater Res B Appl Biomater 69: 104-112, 2004.

4. Devlin JJ, Pomerleau AC, Brent J, Morgan BW, Deitchman S and Schwartz M: Clinical features, testing, and management of patients with suspected prosthetic hip-associated cobalt toxicity: A systematic review of cases. J Med Toxicol 9: 405-415, 2013.

5. Jantzen C, Jorgensen HL, Duus BR, Sporring SL and Lauritzen JB: Chromium and cobalt ion concentrations in blood and serum following various types of metal-on-metal hip arthroplasties: A literature overview. Acta Orthop 84: 229-236, 2013.

6. Pizon AF, Abesamis M, King AM and Menke N: Prosthetic hip-associated cobalt toxicity. J Med Toxicol 9: 416-417,2013.

7. Bradberry SM, Wilkinson JM and Ferner RE: Systemic toxicity related to metal hip prostheses. Clin Toxicol (Phila) 52: 837-847, 2014.

8. MacDonald SJ: Can a safe level for metal ions in patients with metal-on-metal total hip arthroplasties be determined? J Arthroplasty 19 (8 Suppl 3): S71-S77, 2004.

9. Caicedo MS, Pennekamp PH, McAllister K, Jacobs JJ and Hallab NJ: Soluble ions more than particulate cobalt-alloy implant debris induce monocyte costimulatory molecule expression and release of proinflammatory cytokines critical to metal-induced lymphocyte reactivity. J Biomed Mater Res A 93: 1312-1321, 2010.

10. Allen MJ, Myer BJ, Millett PJ and Rushton N: The effects of particulate cobalt, chromium and cobalt-chromium alloy on human osteoblast-like cells in vitro. J Bone Joint Surg Br 79: 475-482, 1997.
11. Anissian L, Stark A, Dahlstrand H, Granberg B, Good V and Bucht E: Cobalt ions influence proliferation and function of human osteoblast-like cells. Acta Orthop Scand 73: 369-374, 2002.

12. Hallab NJ, Vermes C, Messina C, Roebuck KA, Glant TT and Jacobs JJ: Concentration- and composition-dependent effects of metal ions on human MG-63 osteoblasts. J Biomed Mater Res 60: 420-433, 2002.

13. Brown C, Lacharme-Lora L, Mukonoweshuro B, Sood A, Newson RB, Fisher J, Case CP and Ingham E: Consequences of exposure to peri-articular injections of micro- and nanoparticulate cobalt-chromium alloy. Biomaterials 34: 8564-8580, 2013.

14. Sansone V, Pagani D and Melato M: The effects on bone cells of metal ions released from orthopaedic implants. A review. Clin Cases Miner Bone Metab 10: 34-40, 2013.

15. Patntirapong S, Habibovic P and Hauschka PV: Effects of soluble cobalt and cobalt incorporated into calcium phosphate layers on osteoclast differentiation and activation. Biomaterials 30: 548-555, 2009.

16. Andrews RE, Shah KM, Wilkinson JM and Gartland A: Effects of cobalt and chromium ions at clinically equivalent concentrations after metal-on-metal hip replacement on human osteoblasts and osteoclasts: Implications for skeletal health. Bone 49: 717-723, 2011.

17. Shah KM, Wilkinson JM and Gartland A: Cobalt and chromium exposure affects osteoblast function and impairs the mineralization of prosthesis surfaces in vitro. J Orthop Res 33: 1663-1670, 2015.

18. Liu YK, Ye J, Han QL, Tao R, Liu F and Wang W: Toxicity and bioactivity of cobalt nanoparticles on the monocytes. Orthop Surg 7: 168-173, 2015.

19. Schrock K, Lutz J, Mändl S, Hacker MC, Kamprad M and Schulz-Siegmund M: Co (II)-mediated effects of plain and plasma immersion ion implanted cobalt-chromium alloys on the osteogenic differentiation of human mesenchymal stem cells J Orthop Res 33: 325-333, 2015.

20. Moshtaghie AA, Malekpouri P, Moshtaghie E and Rahnamaie F: Cobalt induces alterations in serum parameters associated with bone metabolism in male adult rats: Turk J Biol 38: 561-567, 2014.

21. Dai M, Yuan X, Fan H, Cheng M and Ai J: Expression of receptor activator of nuclear factor kappaB ligand and osteoprotegerin of mice osteoblast induced by metal ions. Zhongguo Xiu Fu Chong Jian Wai Ke Za Zhi 24: 292-295, 2010 (In Chinese).

22. Karsenty G: Transcriptional control of skeletogenesis. Annu Rev Genomics Hum Genet 9: 183-196, 2008.

23. Livak KJ and Schmittgen TD: Analysis of relative gene expression data using real-time quantitative PCR and the 2(-Delta Delta C(T)) method. Methods 25: 402-408, 2001.

24. Schmidt C, Steinbach G, Decking R, Claes LE and Ignatius AA: IL-6 and PGE2 release by human osteoblasts on implant materials. Biomaterials 24: 4191-4196, 2003.

25. Kanaji A, Caicedo MS, Virdi AS, Sumner DR, Hallab NJ and Sena K: Co-Cr-Mo alloy particles induce tumor necrosis factor alpha production in MLO-Y4 osteocytes: A role for osteocytes in particle-induced inflammation. Bone 45: 528-533, 2009.

26. Stein GS and Lian JB (eds): Cellular and Molecular Biology Of Bone. 1st edition. Academic Press, Tokyo, 1993.

27. Zijlstra WP, Bulstra SK, van Raay JJ, van Leeuwen BM and Kuijer R: Cobalt and chromium ions reduce human osteoblast-like cell activity in vitro, reduce the OPG to RANKL ratio, and induce oxidative stress. J Orthop Res 30: 740-747, 2012 . 